\title{
A new framework for performance evaluation system using strategy map: A case study of Islamic Azad University of Semnan
}

\author{
Afsaneh Mozaffari $^{\mathrm{a}}$, Hamid Kalaei ${ }^{\mathrm{b}}$, Mahsa Shahhosseini ${ }^{\mathrm{c}^{*}}$ and Yahya Chaghouee ${ }^{\mathrm{d}}$
}

\author{
${ }^{a}$ Member of the board, Islamic azad University, Science and Research Branch, Department of Social Communication Sciences, Tehran, Iran \\ ${ }^{b}$ Senior Member of Bank Mellat, Iran \\ ${ }^{c}$ Department Of Management, Semnan Branch, Islamic Azad University, Semnan, Iran \\ ${ }^{d}$ Phd Candiate, Islamic Azad University, Science and Research Branch, Department of Media Management, Tehran, Iran

\section{H R O N I C L E}

\section{A B S T R A C T}

Article history:

Received October 20, 2012

Received in revised format

28 January 2013

Accepted 26 March 2013

Available online

March 262013

Keywords:

Performance evaluation system

BSC

Strategy map

Islamic Azad University of semnan
During the past few years, there have been extensive developments on Islamic Azad University, which has led on reduction of managerial flexibility. Therefore, these organizations concentrate on their strategic management via usage of the Balanced Model such as Balanced Score Card (BSC) to consider different organizational perspectives and it is important to have good description of organizational strategies and goals. The strategy map is a primary factor to assess the performance in different organizational activities. In this paper, the performance evaluation system of Islamic Azad University of Semnan is designed by the utilization of strategy map as a prominent part of BSC.

\section{Introduction}

The assessment of the organizational activities performance is considered as an initiating point of scientific management processes in various researches (Maltz, 2003). In management research, the primary objectives of most managers in different organizations are grouped in five categories: Planning, Organizing, Staffing, Directing, Coordinating, Reporting and budgeting (Gulick \& Urwick, 1973). According to this categorization, the assessment and a good control on organizational performance is a prominent function for managers (Neely \& Adams, 2000). In addition, the organizational performance is divided in: (1) Result (outcome); (2) behavior (input). The behaviors are originated from the player and lead to outcome (performance) (Anthony \& Govindarajan, 2001).

Corresponding author. Tel: +989128320560

E-mail: mahsa.shahhosseini@yahoo.com (M. Shahhosseini)

(C) 2013 Growing Science Ltd. All rights reserved.

doi: 10.5267/j.msl.2013.03.025 
The performance management is an integrated and strategic process, which plays essential role on the success of organization through the optimization of role player (personnel) performance (Otley, 1999). The performance measurement system is a portion of performance management system and is utilized as a quantitative measurement for an activity efficiency and effectiveness (Neely \& Adams, 2000).

As noted by Paddock (1997), the performance evaluation is a process according to management concept and principles for goal attainment. Evans and Lindsay (2005) believe that the performance evaluation system is a competitive advantage for organizations. Besides, Simon (2000) recount that performance evaluation system is a key factor for responding to customer expectations. The researches in the field of performance evaluation proceed in two steps. In first step lasted until 1980, the main consideration was about the financial measurement of accounting system (Lebas, 1995).

The second step has started from 1980 and it has been growing, steadily. Some research named this step as "the revolution of performance evaluation" (Baldwin \& Clark, 1992). Many studies (Prowse \& Prowse, 2009; Sole, 2009; Banwet \& Deshmukh, 2008; Hassab et al., 2010; Ramstad, 2009; Lester et al., 2010; De Waal, 2010) focus on the comparison of performance evaluation systems and their effect on the organization. Meanwhile, some researches introduce BSC as the best model for performance evaluation.

For the first time, this model is presented in 1992 by Professor Robert Kaplan and Doctor David Norton as a contemporary system in management and identified the requirements for effective execution of strategies and the implementation of the comprehensive management system and performance improvement. The BSC is a thorough framework for performance evaluation and strategies development. It leads to balance between short-term and long-term goals, financial and non-financial measurements, internal and external performance, internal and external stakeholders, strategies stimuli and obstacles (Grigoroudi et al., 2012).

BSC is a framework for describing and operations of the organizational strategies (Makhijani, \& Creelman, 2008). Therefore, in BSC design the key factors that lead to the readiness of organizational strategies for value creation in future; should be evaluated (Kaplan \& Norton, 2004). BSC is a complete managerial system for managing the strategies execution and measuring organizational performance from four aspects: financial, customer, internal processes, learning and growth but these aspects could be modified according to industrial structure and organizational dynamics (Kaplan \& Norton, 2000; Chen, et al., 2006; Chytas, 2008). It causes to transfer the mission, vision, strategies and functional expectations to the organizational stakeholders. It means that the BSC explains the organizational missions and visions as a causality set in four aspects and considers the organization as an integrated system (Nissen, 2006). These outstanding traits of BSC cause the apllication of it in various industrial and service portions (Xu \& Yeh, 2012).

According to Makhijani and Creelman (2008), the BSC is composed of four dependent components as follows:

1- The strategy map that identifies and explains the organizational strategic goals (if this goal is met, the strategy will execute, successfully).

2- Performance measurements that clarify the progress of organization to the strategic goals.

3- Quantitative goals defined for measurements.

4- Selection and execution of strategic innovation due to link between quantitative goals and performance and meet the strategic goals.

The researcher who proposed BSC believe that the successful execution of organizational strategies is depended to the personnel comprehension of strategies. For access to this comprehension, the 
complex processess that cause the conversion of intangible assets to the tangible outcomes; must be developed (Kaplan \& Norton, 2000). To do so, the researchers proposed the strategy map as a first component in their model that could link between organizational strategies structure by the recognition and extract of key strategic goals and the depiction of cause-effect relations between them (Kaplan \& Norton, 2000). It means that the successful implementation of BSC is expedited with a model that is developed with base the BSC on strategy map (Makhijani \& Creelman, 2008). For example, many research (Jassbi et al., 2011; Huang et al., 2011; Chang et al., 2011; Cebeci et al., 2009; Buytendijk et al., 2011; Tohidi et al., 2010a; Tohidi et al., 2010b) expedite the execution of BSC with the usage of strategy map.

In this paper, the authors concentrate on the identification of goals structure and organizational key measurements, link between as a cause-effect relation and preparation of a comprehensive performance evaluation system.

\section{Literature review}

Some reasechers believe that the BSC is not suitable for academic organizations and is more suitable for profitable organizations (Umashankar \& Dutta, 2007). Therefore, the researchers do not pay attention to the deveelopment of BSC model in academic field such as university and training institutions. Nevertheless, the academic universities implement BSC, extensively. For example, Rossir training institution of south california college applied the BSC as a training effectiveness measurement (Umashankar, \& Dutta, 2007). In addition, the Edenburg college, the south California university, the Ohio university, the California college, the Ukrine college are the other examples that implement the BSC (Walker \& Ainsworth, 2007; Karathanos \& Karathanos, 2005; Umashankar \& Dutta, 2007). As noted by Kaplan and Norton (2000) in non-profit organization, the BSC model is orderly sorted as: vision, customer, internal processes, learning and growth, financial. Wilson et al. (2002) demostrate that the financial part of BSC is changed to stakeholders and is located in the same level with customer in a research which is executed by National British Colombia Office in Canada. In addition, despite they perceive the financial part as the prominent part of BSC in three offices which implement the Balance Card or strategy map; do not explain whether the selected model is related to organizational culture.

However, four key aspects of BSC can be modified with the unique requirment of organization in spite of the similarity between the applied structural aspect in business organization with non-profit and governemental organization. Without understanding the compelete financial structure including reources and budget, the organization is not able to meet vision and mission; so, the non-profit organization must emphasize the financial cost and advantages of performance management. Many non-profit organizations have admireable vision and mission, nevertheless, support it, less financially. Meanwhile, the research demonstrates that fourty-nine percentage of organization believe that the financial measurement is paramount aspect (Niven, 2002).

\section{Design of performance evaluation system with implementation of strategy map in Islamic Azad University of Semnan (IAUS)}

Fig. 1 demonstrate how different steps of performance evaluation system design is related to each other and the following steps summarizes the proposed model of this paper,

Step I. The main mission of the Islamic Azad University (IAU) is the spread of knowledge and skill and the training of the creative person in different fields of sciences and technologies with the quality development of academic life. In addition, it is responsible for the development of research and training services and responding to the various research and training expectation of their stakeholders. The IAU as one of the biggest universities in the Middle East region account for the science development and spread, so, the economic, social and cultural promotion. In addition, it must be 
concentrated on its basic values, which lead to keep the Islamic identity and try to fill the information gap with the creation of a scientific competitive environment by the participation of other research and training institutions and providing appropriate training programs.

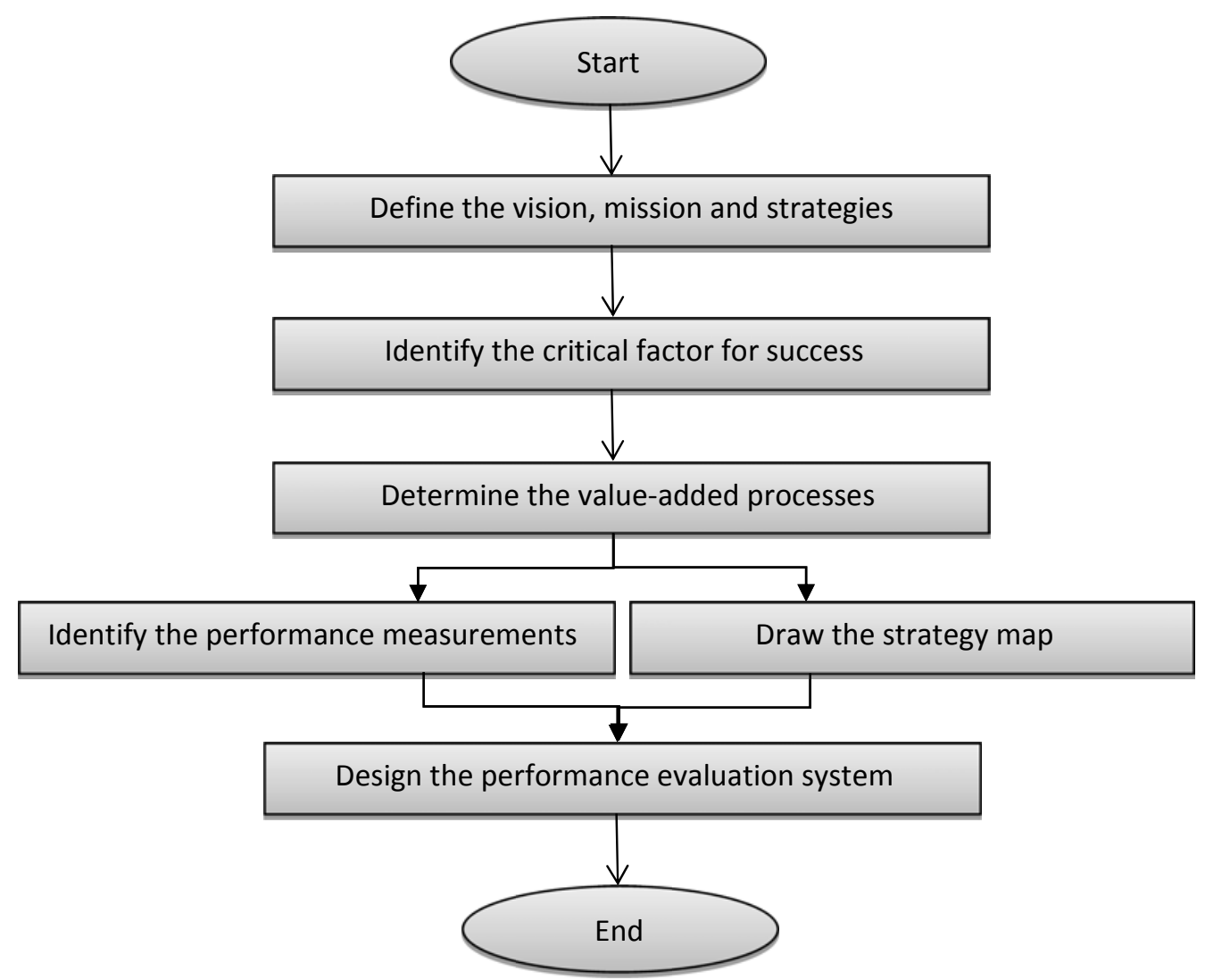

Fig. 1. The framework of the performance evaluation system design

The IAU mission is demonstrated a university which is: "entrepreneurship and effective in economic growth and development of country; superior in providing training and research services to different level of society; pioneer in development of science and theory in west-south of Asia; including advanced research center according to the international standards; responding to new expectations of society such its students will form the future society”.

The IAUS is defined the following strategies for four next years (2012-2016):

1. The reduction of financial dependency to students' payments through the reinforcement of software and hardware abilities

2. The modification, review and redesign of key processes to reinforce the responding ability to the new needs of university (e.g. the modification of salary system, administration structure, the development of its implementation, etc.)

3. The launch and development of the incubator centers to acquire revenue through research activities (e.g. the sale of the scientific patent)

4. The training improvement

Step II. The IAUS key strategic concepts and value-added processes are demonstrated in Table 1. 
Table 1

The strategic information of IAUS

\begin{tabular}{|c|c|c|c|c|c|}
\hline Critical Factor & Basic requirements & Solution & Aspect & Value-added process & Reinforcement solution \\
\hline \multirow[t]{2}{*}{$\begin{array}{l}\text { The development and } \\
\text { improvement of effective and } \\
\text { efficient relation with } \\
\text { industries }\end{array}$} & \multirow{2}{*}{$\begin{array}{l}\text { The creation of an } \\
\text { active unit that is } \\
\text { responsible for } \\
\text { relations with } \\
\text { industries } \\
\text { The empowerment } \\
\text { professors }\end{array}$} & $\begin{array}{l}\text { The creation of an outsourcing } \\
\text { unit for relations with } \\
\text { industries as a percentage of } \\
\text { contracts }\end{array}$ & Customer & $\begin{array}{l}\text { The industrial } \\
\text { relationship process }\end{array}$ & $\begin{array}{l}\text { The appropriation of the defined } \\
\text { percentage of study projects' } \\
\text { income to their members }\end{array}$ \\
\hline & & $\begin{array}{l}\text { To hold on-the-job training } \\
\text { courses for professors }\end{array}$ & $\begin{array}{l}\text { Learning and } \\
\text { growth }\end{array}$ & $\begin{array}{l}\text { The professor } \\
\text { empowerment } \\
\text { process }\end{array}$ & $\begin{array}{l}\text { The creation of sabbatical for } \\
\text { professors in foreign universities }\end{array}$ \\
\hline \multirow{2}{*}{$\begin{array}{l}\text { Creating an efficient system of } \\
\text { intellectual and moral } \\
\text { ownership for the sale of } \\
\text { scientific patents }\end{array}$} & \multirow{2}{*}{$\begin{array}{l}\text { An independent legal } \\
\text { unit for university } \\
\text { A marketing unit for } \\
\text { sale of the scientific } \\
\text { patents }\end{array}$} & \multirow{2}{*}{$\begin{array}{l}\text { Creating an independent and } \\
\text { powerful legal unit for } \\
\text { university } \\
\text { Creating a marketing unit for } \\
\text { patents }\end{array}$} & $\begin{array}{l}\text { Academic } \\
\text { credits }\end{array}$ & \multirow{2}{*}{$\begin{array}{l}\text { The legal process } \\
\text { The patent marketing } \\
\text { process }\end{array}$} & \multirow{2}{*}{$\begin{array}{l}\text { The part time cooperation with } \\
\text { external legal centers } \\
\text { The part time contract with } \\
\text { external marketing centers }\end{array}$} \\
\hline & & & $\begin{array}{l}\text { Customer } \\
\text { Financial }\end{array}$ & & \\
\hline \multirow[t]{2}{*}{$\begin{array}{l}\text { Developing and equipping in } \\
\text { order to promoting the } \\
\text { university at least in one of the } \\
\text { introduced scientific } \\
\text { educational field in the country }\end{array}$} & \multirow[t]{2}{*}{$\begin{array}{l}\text { Identifying and } \\
\text { developing the applied } \\
\text { field in the country }\end{array}$} & $\begin{array}{l}\text { Identifying the applied field in } \\
\text { the country }\end{array}$ & $\begin{array}{l}\text { Learning and } \\
\text { growth }\end{array}$ & $\begin{array}{l}\text { The process of } \\
\text { identifying field of } \\
\text { being unique }\end{array}$ & $\begin{array}{l}\text { 1. collecting and recording the } \\
\text { research activities of students, } \\
\text { professors and departments } \\
\text { 2. the evaluation of departments } \\
\text { according to the research scores }\end{array}$ \\
\hline & & $\begin{array}{l}\text { Development and promotion } \\
\text { of the applied field in the } \\
\text { country }\end{array}$ & $\begin{array}{l}\text { Academic } \\
\text { credits }\end{array}$ & $\begin{array}{l}\text { The process of } \\
\text { developing and } \\
\text { promoting field of } \\
\text { being unique }\end{array}$ & $\begin{array}{l}\text { 1. To hold the national } \\
\text { championships in the applied } \\
\text { field and relationships with the } \\
\text { research centers in the applied } \\
\text { field } \\
2 \text {. To hold the national and } \\
\text { international conference in the } \\
\text { applied field }\end{array}$ \\
\hline $\begin{array}{l}\text { Creation of incentive points for } \\
\text { development of software } \\
\text { capitals( the empowerment of } \\
\text { existing personnel and the } \\
\text { employment of new professor, } \\
\text { personnel and students }\end{array}$ & $\begin{array}{l}\text { The development of } \\
\text { incentive points }\end{array}$ & $\begin{array}{l}\text { 1. The creation of sabbatical } \\
\text { and academic tours for } \\
\text { researchers } \\
\text { 2. The increase of paper and } \\
\text { research proposal } \\
\text { incentives(cash and other } \\
\text { kinds) } \\
\text { The increase of rewards, } \\
\text { welfare and cultural services } \\
\text { for professors and personnel ( } \\
\text { e.g. home services and the end } \\
\text { of year bonus) }\end{array}$ & $\begin{array}{l}\text { Welfare and } \\
\text { cultural }\end{array}$ & $\begin{array}{l}\text { The incentive points } \\
\text { development process }\end{array}$ & $\begin{array}{l}\text { The appropriation of the excess } \\
\text { outcomes to the relevant persons }\end{array}$ \\
\hline \multirow[t]{2}{*}{$\begin{array}{l}\text { IT application and its } \\
\text { institutionalization in key } \\
\text { processes of the university }\end{array}$} & $\begin{array}{l}\text { The preparation of } \\
\text { hardware and software } \\
\text { equipment }\end{array}$ & $\begin{array}{l}\text { The reinforcement of IT } \\
\text { department }\end{array}$ & $\begin{array}{l}\text { Internal } \\
\text { processes } \\
\text { Financial }\end{array}$ & \multirow[t]{2}{*}{ IT process } & \multirow[t]{2}{*}{$\begin{array}{l}\text { The creation of a supporting unit } \\
\text { for solving the hardware and } \\
\text { software problems }\end{array}$} \\
\hline & Training of personnel & $\begin{array}{l}\text { The reinforcement of personnel } \\
\text { on-the-job trainings }\end{array}$ & $\begin{array}{l}\text { Learning and } \\
\text { growth }\end{array}$ & & \\
\hline $\begin{array}{l}\text { Creating and equipment of the } \\
\text { growth centers for converting } \\
\text { the scientific results to saleable } \\
\text { scientific patents }\end{array}$ & $\begin{array}{l}\text { Creation and } \\
\text { development of } \\
\text { specific growth center }\end{array}$ & $\begin{array}{l}\text { 1. The creation of specific } \\
\text { growth centers in the } \\
\text { university } \\
2 \text {. The national and } \\
\text { international cooperation with } \\
\text { research centers }\end{array}$ & $\begin{array}{l}\text { Academic } \\
\text { credits }\end{array}$ & $\begin{array}{l}\text { Scientific patent } \\
\text { creation process }\end{array}$ & $\begin{array}{l}\text { To contract with an external } \\
\text { growth center for selling the } \\
\text { scientific patents }\end{array}$ \\
\hline
\end{tabular}

Step III. Fig. 2 illustrates the strategy map of the IAUS as the outcome of this step.

Financial

Academic process

Customer

Welfare and culture

Internal process

Learning and growth

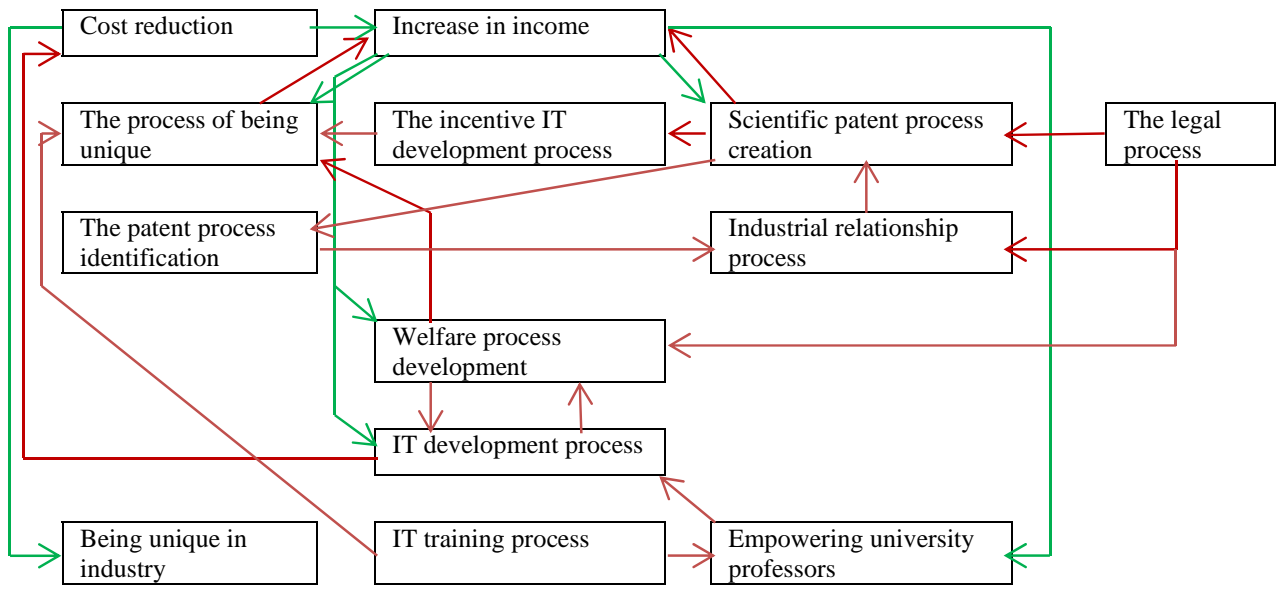

Fig. 2. The strategy map of the IAUS 


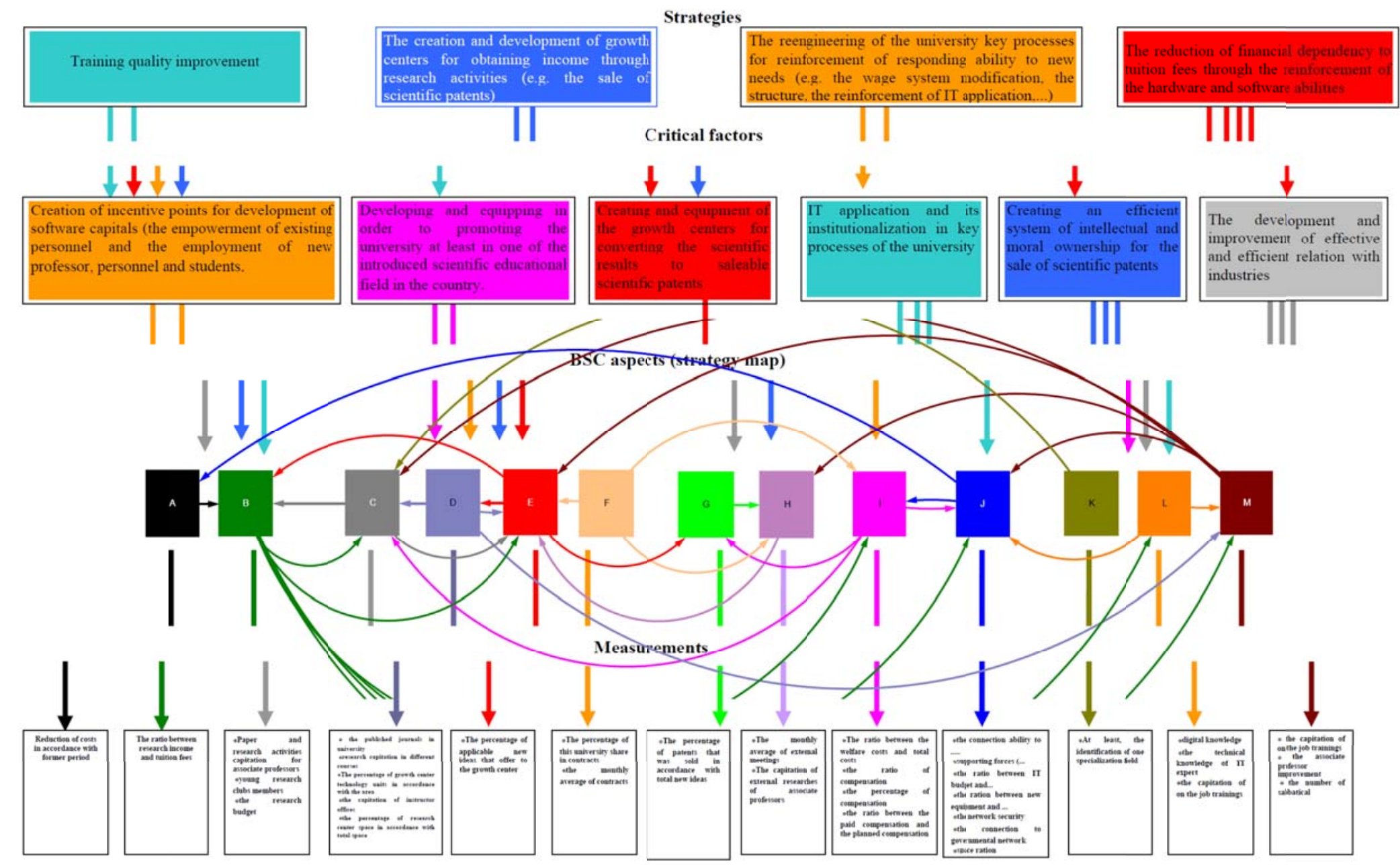

Fig. 3. The performance evaluation system of IAUS 
Step IV. The key performance measurements of each value-added process of the IAUS are reflected in the low level of Fig 3.

Step V. According to the information acquired in former steps, the performance evaluation system of IAUS is introduced in Fig 3.

\section{Conclusion}

One of the main goals of this paper, according to the presented principles, has been the provision of a system for the performance evaluation in Islamic Azad University of Semnan. This system has been developed by strategy map and the result has been illustrated in a comprehensive diagram (Fig. 2). This diagram is practically covered all aspects of critical factors for the success and the strategies of Islamic Azad University of Semnan. In addition, the relationships between BSC's aspects, critical factors for success and value-added processes have been defined based on strategy map. These relationships are some bases for the performance evaluation, the ranking of strategy levels, the critical factors for success, value-added processes and performance measurements.

\section{Reference}

Agrawal, S. (2008). Competency based balanced scorecard model: An integrative perspective. Indian Journal of Industrial Relations, 8(3), 12-18.

Anthony, R.N., \& Govindarajan, V. (2001). Management Control System. $10^{\text {th }}$ ed., McGraw-Hill Irwin.

Baldwin, C. Y., \& Clark, K. B. (1992). Capabilities and capital investment: New perspectives on capital budgeting. Journal of Applied Corporate Finance, 5(2), 67-82.

Banwet, J. D. K., \& Deshmukh, S. G. (2008). Evaluating Performance of National R\&D Organizations Using Integrated DEA-AHP Technique. International Journal of Productivity and Performance Management, 57(5), 370-388.

Bukh, P. N., \& Malmi, T. (2005). Reexamining cause-and-effect principal of the balances scorecard. In J. Mourtisen, S. Jönsson (Eds.), Northern Lights in Accounting. Stockholm, Libber.

Buytendijk, F., Hatch, T., \& Micheli, P. (2010). Scenario-based strategy maps. Business Horizons, 53, 335-347.

Cebeci, U. (2009). Fuzzy AHP-based decision support system for selecting ERP systems in textile industry by using balanced scorecard. Expert Systems with Applications, 36(5), 8900-8909.

Chang, B., Chang, C.W., \& Wu, C.H. (2011). Fuzzy DEMATEL method for developing supplier selection criteria. Expert Systems with Applications, 38(3), 1850-1858.

Chen, S.H., Yang, C.C., \& Shiau, J.Y. (2006). The application of balanced scorecard in the performance evaluation of higher education. The TQM Magazine, 18(2), 190-205.

Chytas, P. (2008). A proactive fuzzy cognitive balanced scorecard. IEEE World Congress on Computational Intelligence Systems, 1331-1338.

De Waal, A. (2010). Performance-driven behavior as the key to improved organizational performance. Journal of Measuring Business Excellence, 14(1), 79- 95.

Evans, J. R., \& Lindsay, W. (2005). The Management and Control of Quality. Mason Oh.: Thomson South-Western.

Grigoroudis, E., Orfanoudaki, E., \& Zopounidis, C. (2012). Strategic performance measurement in a healthcare organization: A multiple criteria approach based on balanced score. Omega, 40, 104-119.

Gulick, L., \& Urwick, L. (1973). Papers on the Science of Administration, N.Y., Institute Public Administration.

Hassab, E., Hassan, R., Amal, A., \& Said, E. M. (2010). Nonfinancial performance measures and earnings management. Advances in Management Accounting, 18, 55-79.

Huang, H. C., Lai, M. C., \& Lin, L. H. (2011). Developing strategic measurement and improvement for the biopharmaceutical firm: Using the BSC hierarchy. Expert Systems with Applications, 38(5), 4875-4881.

Jassbi, J., Mohamadnejad, F., \& Nasrollahzadeh, H. (2011). A Fuzzy DEMATEL framework for modeling cause and effect relationships of strategy map. Expert Systems with Applications, 38, 59675973. 
Kaplan, R. S., \& Norton, D. P. (2004). Strategy maps: Converting intangible assets into tangible outcomes. Boston, MD: Harvard Bus. School Press.

Kaplan, R. S., \& Norton, D. P. (2002). Building the balanced scorecard in public sector. Balanced scorecard report from interview with Rick Pagsibigan, September 19.

Kaplan, R. S., \& Norton, D.P. (2000). The strategy-focused organization: How balanced scorecard companies thrive in the new business environment. Harvard Business School Press.

Kaplan, R., \& Norton, D. (1996). Using the balanced scorecard as a strategic management system. Harvard Business Review (January. February), 74(1), 75.85.

Lebas, M. J. (1995). Performance measurement and performance management. International Journal of Production Economics, 41, 23-35.

Lester, D. L., Parnell, A. J., \& Carraher, S. (2010). Assessing the desktop manager. Journal of Management Development, 29(3), 246-264.

Makhijani, N., \& Creelman, J. (2008). How leading organizations successfully implement corporate strategy with the balanced scorecard. The OTI Thought Leadership Series, 1, 1-16.

Maltz, A. C., Shenhar, A. J., \& Reilly, R. R. (2003). Beyond the balanced scorecard: Refining the search for organizational success measures. Long Range Planning, 36(2), 187-204.

Neely, A. D., \& Adams, C. A. (2000). Perspective on performance: the performance prism, centre for business performance, Canfield School of management, UK.

Neely Andy, G., \& Platts, K. (1995). Performance measurement system design. International Journal of Operations and production Management, 15(4), 80-116.

Nissen, V. (2006). Modeling corporate strategy with the fuzzy balanced scorecard. In: Hüllermeier E, Kruse R, Nürnberger A, Strackeljan J (eds.): Proceedings Symposium on Fuzzy Systems in Computer Science FSCS 2006, Magdeburg. P.P. 121-138.

Otley, D. (1999). Performance management: a framework for management control systems research. Management Accounting Research, 10, 362-382.

Paddock, S. C. (1997). Benchmarks in management training. Public Personnel Management, 26(4), 441-460.

Prowse, P., \& Prowse, J. (2009). The dilemma of performance appraisal. Journal of Measuring Business Excellence, 13(4), 69-77.

Ramstad, E. (2009). Promoting performance and the quality of working life simultaneously, International Journal of Productivity and Performance Management, 58(5), 423-436.

Simons, R. (2000). Performance Measurement Control Systems for Implementing Strategy. N. J.: Prentice Hall, P.P. 5-35.

Sole, F. (2009). A management model and factors driving performance in public organizations. Measuring Business Excellence, 13(4), 3-11.

Tohidi, H., Jafari, A., \& AzimiAfshar, A. (2010a). Strategic planning in Iranian educational organizations. Procedia Social and Behavioral Sciences, 2, 3904-3908.

Tohidi, H., Jafari, A., \& AzimiAfshar, A. (2010b). Using balanced scorecard in educational organizations. Procedia Social and Behavioral Sciences, 2, 5544-5548.

Wiersma, E. (2009). For which purposes do managers use Balanced Scorecards?: An empirical study. Management accounting research, 20(4), 239-251.

Xu, Y., \& Yeh, C. H. (2012). An integrated approach to evaluation and planning of best practices. Omega, 40, 65-78.

Kaplan, P. S., \& Norton, D. P. (2001). The strategy-focused organization: How balanced scorecard companies thrive in the new business environment. Boston, MA: Harvard Business School Press.

Karathanos, D., \& Karathanos, P. (2005). Applying the balanced scorecard to education. Journal of Education for Business, March/April, P.P. 222-231; ISSN-0883-232.

Niven, P.P. (2002). Balanced scorecard step by step, John Wiley \& Sons, New York, N.Y. Owlia, M. S. and Aspinwll, E. M. (1996), Quality in higher education: a survey, Total Quality Management, P.P. 161-71.

Umashankar, V., \& Dutta, K. (2007). Balanced scorecards in managing higher education institutions: An Indian perspective. International Journal of Educational Management, 21(7), 54-67.

Walker, K. B., \& Ainsworth, P. L. (2007). Achieving competitive advantage in departments of accounting: Management principles and the balanced scorecard. Academy of Accounting and Financial Studies Journal, 11(1), 65-82. 